\title{
Pemetaan Banjir Menggunakan Hec - Ras Pada Kebun Pisang Pt Agro Prima Sejahtera Di Sekampung Udik, Lampung Timur
}

\author{
(Flood Mapping Using Hec - Ras In Banana Field Of Pt Agro Prima Sejahtera At \\ Sekampung Udik, Lampung East)
}

\author{
Aditya Mandagi ${ }^{1}$ dan Yuli Suharnoto ${ }^{1 *}$ \\ ${ }^{1}$ Departemen Teknik Sipil dan Lingkungan, Fakultas Teknologi Pertanian, Institut Pertanian Bogor. \\ J1. Raya Dramaga, Kampus IPB Dramaga, PO BOX 220, Bogor, Jawa Barat Indonesia \\ *Penulis korespondensi: yuli.suharnoto@gmail.com
}

\begin{abstract}
Floods can occur in the form of inundation such as agricultural land, settlements, and the city centre. The purpose of this research was to map the spread of flood areas in banana plantation of PT Agro Prima Sejahtera in DAS Way Sekampung using the ArcGIS application and HEC-RAS. The benefits of the research was to provide information for the local government, on the flood-prone areas as material considerations for drafting plans for the management of the watershed. The hydrograph discharge was obtained from the results of the simulation of the SWAT application. The peak discharge of $97.90 \mathrm{~m}^{3} / \mathrm{s}$ was occurred on 6 October 2007, minimum discharge of $19.25 \mathrm{~m}^{3} / \mathrm{s}$ was occurred on 14 November 2007, and the mean average discharge was $41.14 \mathrm{~m}^{3} / \mathrm{s}$. Cross section of trapezoid-shaped channels had an area of $178.52 \mathrm{~m}^{2}$, the elevation was $0.5 \mathrm{~m} / \mathrm{segmen}$, the width of the tunnel base was $9.1 \mathrm{~m}$, and water level in the channel was $6.23 \mathrm{~m}$. The height of the channel was $5 \mathrm{~m}$, and the flood occurred on the channel when the maximum condition was $2.17 \mathrm{~m}$. Manning coefficients used on meandering, sloping, and grassy ground channel type was 0.025. The total flooding area when the maximum discharge was $32.48 \mathrm{~m}^{2}$ and on the minimum condition was $0.001 \mathrm{~m}^{2}$ which was occurred in the upper river.
\end{abstract}

Key words: flood, hydrograph, discharge, HEC-RAS

\section{PENDAHULUAN}

Banjir menjadi permasalahan rutin yang sering dihadapi oleh warga masyarakat yang tinggal pada wilayah aliran sungai. Masyarakat sadar akan risiko bahaya dan kerugian yang diakibatkan oleh bencana banjir, namun masyarakat tetap bersikeras untuk tinggal di wilayah rentan tersebut dan sulit untuk direlokasi ke lokasi yang lebih aman dari bahaya banjir. Oleh sebab itu, untuk meminimalkan kerugian yang terjadi akibat banjir, salah satu tindakan yang dilakukan dengan menangani sumber terjadinya banjir atau genangan, yaitu penanganan wilayah sungai. Risiko bahaya dan kerugian dapat dikurangi dengan menerapkan manajemen risiko bencana, yang manfaatnya dapat mengurangi kemungkinan terjadinya bahaya dan mengurangi daya rusak suatu bahaya yang tidak dapat dihindarkan (Santoso 2013).

Daerah aliran sungai (DAS) banyak digunakan oleh beberapa ahli dengan makna atau pengertian yang berbedabeda, ada yang menyamakan dengan cacthment area, watershed, atau drainage basin. Daerah aliran sungai merupakan keseluruhan kawasan pengumpul suatu sistem tunggal, sehingga dapat disamakan dengan cacthment area. Daerah aliran sungai (DAS) merupakan daerah yang dibatasi oleh topografi sebagai pemisah air yang terkeringkan oleh sungai atau 
sistem saling berhubungan sedemikian rupa sehingga semua aliran sungai yang jatuh di dalam akan keluar dari saluran lepas tunggal dari wilayah tersebut (Sudaryono 2002).

Pengelolaan Daerah Aliran Sungai (DAS) merupakan usaha manusia untuk memanfaatkan sumber - sumber air dalam pemenuhan kebutuhan sehari - hari secara berkesinambungan. Akibat perubahan tata guna lahan (land use change) dari rural menjadi urban suatu daerah aliran sungai secara jangka panjang akan merubah siklus hidrologi sehingga mendorong perbedaan cuaca, fenomena tersebut menyebabkan terjadinya perubahan iklim secara ekstrim yang berkepanjangan. Fenomena tersebut melanda diberbagai wilayah Indonesia pada beberapa tahun terakhir ini. Perubahan tata guna lahan ini menunjukkan berkurnagnya fungsi hutan pada suatu DAS sebagai waduk alam dan sebagai suplai air pada musim kemarau (Kastamto 2012).

Kegiatan perubahan tata guna lahan dan pembuatan bangunan konservasi dilaksanakan di daerah bagian hulu DAS tidak hanya memberikan dampak di daerah dimana kegiatan tersebut berlangsung, kegiatan tersebut juga akan menimbulkan dampak pada bagian hilir dalam bentuk perubahan fluktuasi debit, transport sedimen, serta material terlarut dalam sistem aliran air lainnya. Sebagai contoh, erosi yang terjadi di daerah bagian hulu akibat dari praktek cocok tanam yang tidak mengikuti prinsip konservasi tanah dan air, tidak hanya terjadi di daerah dimana terjadi erosi tersebut berlangsung penurunan produtivitas lahan, akan menimbulkan dampak di daerah hilir dalam bentuk penurunan kapasitas tampung waduk, pendangkalan sungai saluran - saluran irigasi, meningkatkan resiko terjadinya banjir, dan menurunkan luas lahan irigasi bahkan mengganggu jalannya operasi listrik tenaga air (Putrinda 2012).
Banjir dapat berupa genangan pada lahan yang biasanya kering seperti pada lahan pertanian, permukiman, dan pusat kota. Banjir dapat terjadi karena debit atau volume air yang mengalir pada suatu sungai diatas kapasitas maksimumnya. Luapan air pada umumnya tidak menjadi permasalahan bila tidak mengakibatkan kerugian, korban meninggal, materil, tidak merendam permukiman dalam waktu lama, dan tidak menimbulkan persoalan lain bagi kehidupan sehari-hari. Bila genangan air terjadi cukup tinggi dalam waktu yang lama maka, hal tersebut akan mengganggu aktivitas manusia. Dalam sepuluh tahun terakhir ini, luas area dan frekuensi banjir semakin bertambah dengan kerugian yang makin besar (Rosyidie 2013).

Berdasarkan observasi lapang, PT Agro Prima Sejahtera termasuk wilayah yang terkena dampak dari banjir akibat luapan Way Sekampung. PT Agro Prima Sejahtera (APS) adalah perusahaan yang bergerak di bidang perkebunan buahbuahan tropis dengan produk utama berupa pisang dan nanas. Perkebunan terletak di Kecamatan Sekampung Udik, Lampung Timur dengan luas lahan lebih dari 500 ha.

\section{METODOLOGI}

Pelaksanaan penelitian ini dilaksanakan selama 2 bulan. Penelitian ini dilakukan di sepanjang aliran Daerah Aliran Sungai Way Sekampung, Kecamatan Sekampung Udik, Kabupaten Lampung Timur, Provinsi Lampung. Bahan yang diperlukan antara lain berupa data primer (data titik koordinat) dan data sekunder (data debit banjir dari simulasi SWAT, curah hujan, dan peta RBI Lampung). Alat yang digunakan adalah laptop yang dilengkapi software (ArcGIS 10.3 (extention HEC - geoRAS), HECRAS 5.0.3, Ms. Excel, MS. Word), GPS dan GPS RTK (Real Time Kinematic). 
Prosedur penelitian dapat dilihat pada Gambar 2 disajikan berupa diagram alir.

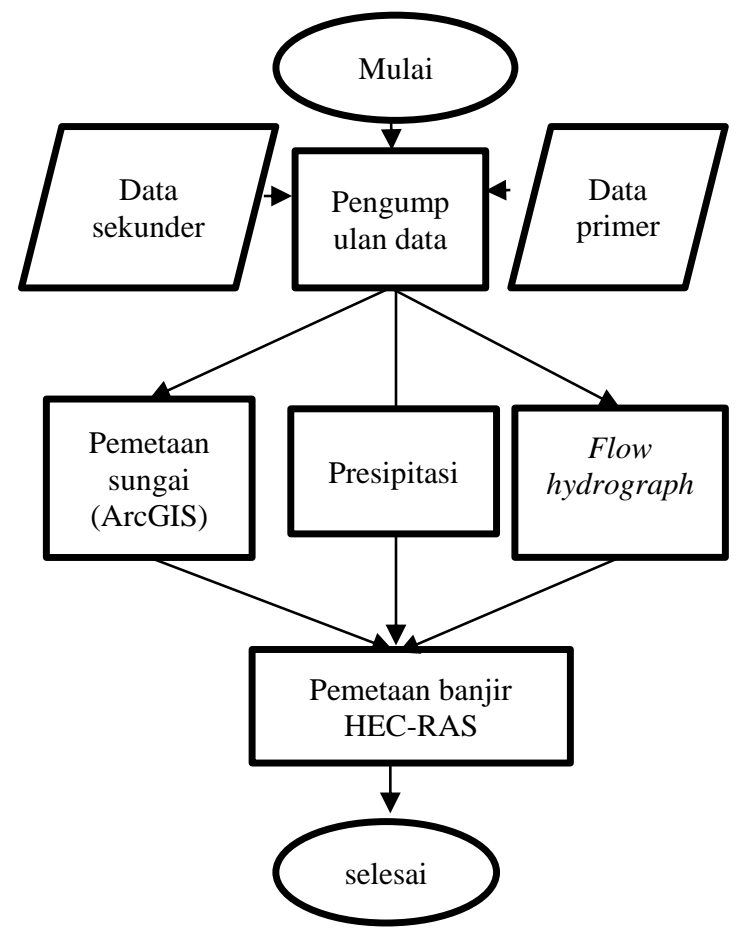

\section{HASIL DAN PEMBAHASAN}

\section{Kondisi Umum DAS Way Sekampung}

DAS Way Sekampung secara letak geografis antara $104^{\circ} 31^{\prime} 00^{\prime \prime}$ - $105^{\circ} 49^{\prime} 00^{\prime \prime}$ BT dan $05^{\circ} 10^{\prime} 00^{\prime \prime}-05^{\circ} 50^{\prime} 00^{\prime \prime} L S$, sedangkan secara administratif DAS Way Sekampung melintasi tujuh kabupaten atau kota, yaitu kabupaten Lampung Selatan, Tanggamus, Lampung Timur, Pesawaran, Pringsewu, Kota Bandar Lampung dan Kota Metro. DAS Way Sekampung dibagi menjadi enam sub DAS, yaitu sub DAS Sekampung Hulu, sub DAS Sekampung Hilir, sub DAS Semah, sub DAS Bulok, sub DAS Kandis dan sub DAS Ketibung, saluran sungai merupakan tanah berkelok.

Lahan perkebunan milik PT Agro Prima Sejahtera merupakan lahan perkebunan pisang dengan luas 500 hektar, lahan tersebut berdampingan dengan DAS Way Sekampung, saluran pada DAS way Sekampung permukaannya tersusun dari tanah yang berkelok. Berdasarkan pengamatan pada saat banjir menutupi gubuk atau perumahan warga setempat.

Pembuatan peta kontur dilakukan dengan menggunakan GPS dan RTK, GPS digunakan hanya sebagai nilai pembanding dari nilai yang didapatkan dari RTK, dari kedua alat tersebut didapat nilai koordinat $\mathrm{X}$, koordinat $\mathrm{Y}$, dan nilai elevasi $\mathrm{Z}$ pembuatan peta kontur tersaji dalam bentuk Gambar 3 .

Pembuatan peta kontur berdasarkan dari hasil pengukuran langsung di lapangan yang kemudian diolah menggunakan aplikasi ArcGIS. Titik terendah adalah $-2.47 \mathrm{mdpl}$. Angka tersebut menunjukkan lembah, dan titik tertinggi terdapat pada ketinggian 8.68 mdpl membentuk bukit.

\section{Debit (flow hydrograph)}

Debit (flow hidrograph) didapatkan berdasarkan simulasi dengan aplikasi SWAT debit (flow hydrograph) juga disajikan dalam bentuk kurva pada Gambar 3. Gambar 3 menggambarkan kurva hidrograf yaitu kurva perbandingan antara debit dengan muka air, debit yang digunakan merupakan debit puncak yang dihasilkan simulasi SWAT. Data debit yang digunakan pada 01 agustus 2007 hingga 30 November 2007 interval waktu yang digunakan selama empat bulan. Debit puncak sebesar $97.90 \mathrm{~m}^{3} /$ detik terjadi pada 06 Oktober 2007, debit minimum terjadi sebesar $19.25 \mathrm{~m}^{3} /$ detik terjadi pada bulan $19.25 \mathrm{~m}^{3} /$ detik terjadi pada 14 November 2007, dan rata - rata debit terjadi sebesar $41.14 \mathrm{~m}^{3} /$ detik.

\section{Pemetaan Ruas Sungai ArcGIS}

Pemetaan ruas sungai menggunakan aplikasi ArcGIS dengan bantuan extention berupa HEC - geoRAS. Data yang digunakan pada pemetaan ArcGIS diantaranya peta batas wilayah PT 
APS, peta sungai daerah Lampung, dan data peta kontur. data - data tersebut diproyeksikan dalam satu koordinat D_WGS_1984 48S untuk wilayah Indonesia bagian barat dengan bantuan extention HEC - GeoRAS dibuat pemetaan sungai, tepi sungai bagian kiri, tepi sungai bagian kanan, arah aliran dan cross section (Gambar 4). Cross section dibuat sebanyak 31 buah dengan jarak antar cross section sepanjang $125 \mathrm{~m}$, lebar masing - masing cross section seragam yaitu $100 \mathrm{~m}^{2}$.

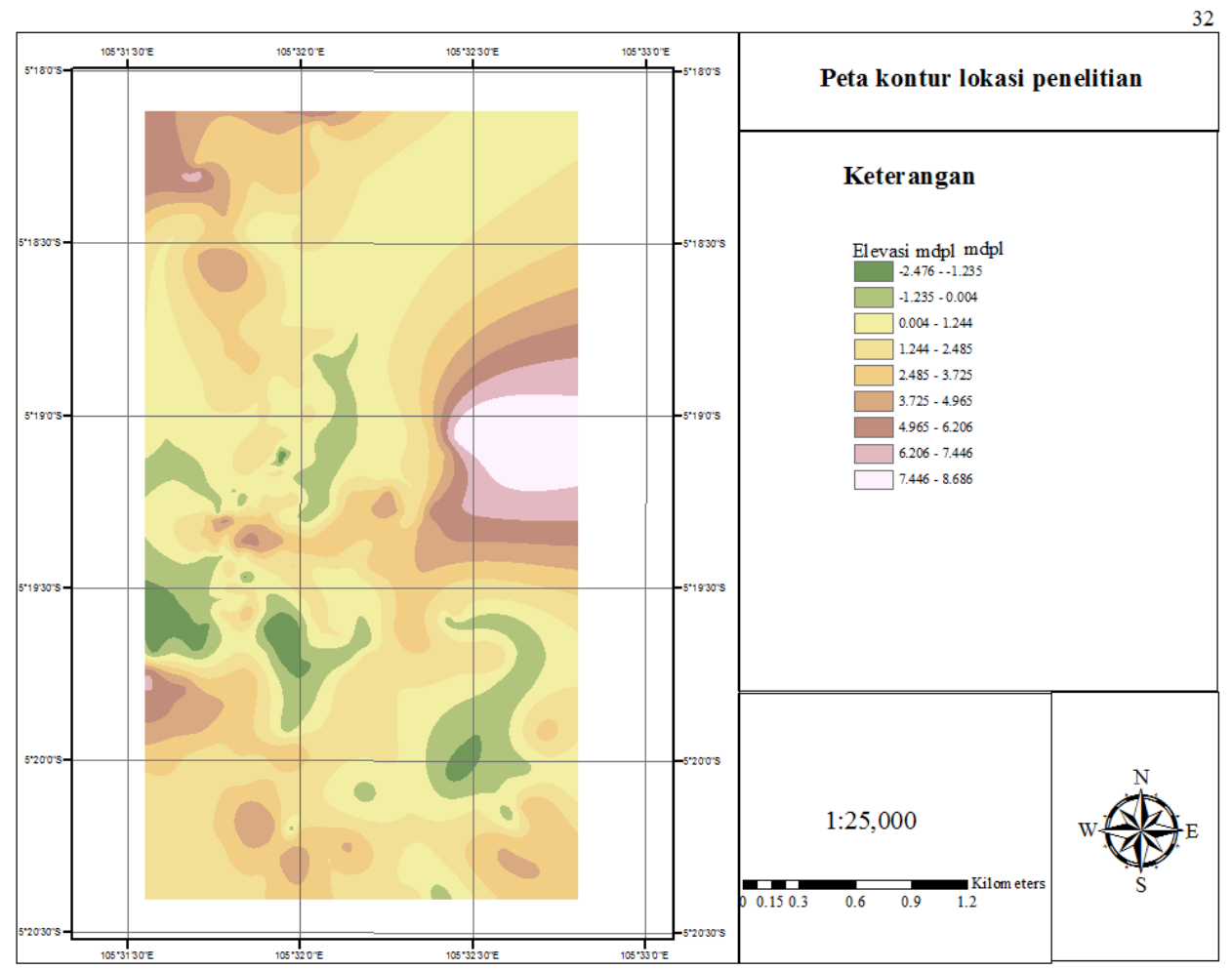

Gambar 2 Peta kontur lokasi penelitian

Flow hydrograph

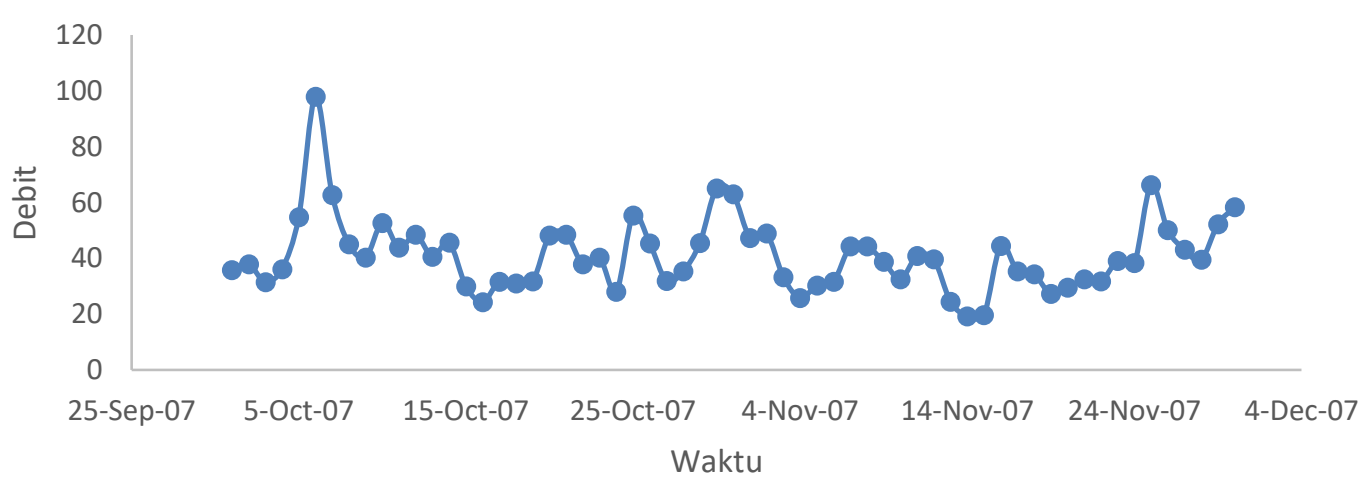

Gambar 3 Kurva hidrograf simulasi SWAT 


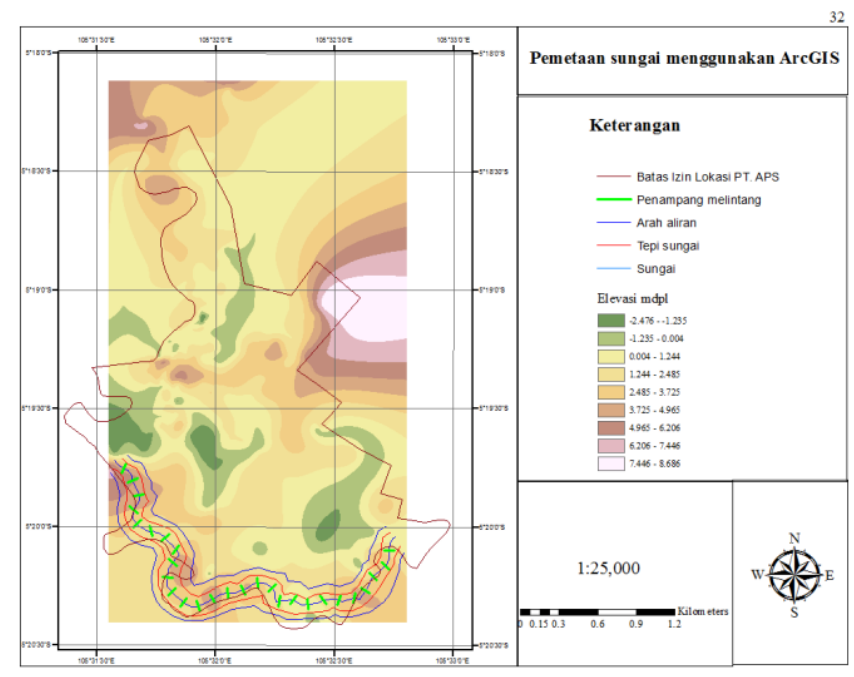

Gambar 4 Pemetaan sungai menggunakan ArcGIS

\section{Presipitasi}

Presipitasi merupakan air yang jatuh dari atmosfer ke bumi dengan intensitas dan jumlah tertentu, presipitasi dapat berupa hujan, salju, uap air, dan kabut (Mustofa et al 2015). Perhitungan dilakukan menggunakan data curah hujan rata-rata yang bersumber dari web National Centers for Environmental Prediction (NCEP) Climate Forecast System Reanalysis (CFSR) globalweather dan curah hujan dari Tropical Rainfall Measuring Mission (TRMM).

Pada Gambar 5, curah hujan maksimum yang terjadi sebesar $24.96 \mathrm{~mm}$ terjadi pada 07 Oktober 2007, curah hujan minimum yang terjadi sebesar $0.0001 \mathrm{~mm}$ terjadi pada 02 Agustus 2007, dan curah hujan rata-rata yang terjadi selama empat bulan sebesar $4.008 \mathrm{~mm}$. Perhitungan ini merupakan perhitungan tambahan yang perlu diperhatikan dalam pemetaan banjir.

\section{Pemetaan banjir HEC-RAS}

Pemetaan menggunakan HEC RAS, data pemetaan pada ArcGIS di export ke HEC - RAS. Geometri data yang dihasilkan dengan menggunakan 2D flow area oleh HEC - RAS. Pemetaan banjir data yang digunakan diantaranya peta kontur, curah hujan rata - rata (TRMM), koefisien runoff, debit flow hydrograph, dan model sungai. Teknik pemetaan menggunakan hydrology modelling. Data berupa kontur yang menunjukkan garis-garis ketinggian wilayah diproses untuk menjadi DEM dan dilakukan suatu pemetaan untuk mencari larian air, akumulasi aliran serta konsentrasi aliran air (Purwono 2013).

Gambar 6 menunjukkan geometri data merupakan hasil lanjutan dari Arcgis, kemudian dibuat $2 D$ flow area merupakan batasan wilayah banjir dibuat dalam bentuk 2 dimensi. Terlihat cross section di bagian hulu dengan nomer 4250, dan pada bagian hilir cross section dengan nomer 125. Penamaan tersebut digunakan karena interval jarak antar cross section sepanjang $125 \mathrm{~m}$ terdapat 31 buah cross section pada $2 D$ flow area tersebut. Pembuatan 2D flow area dibuat menutupi seluruh permukaan peta, untuk mamperhitungkan air dari presipitasi yang berada di lahan.

Berdasarkan pada Gambar 7, bentuk penampang melintang sungai pada bagian hulu tersebut dengan luas 
penampang saluran sebesar $178.52 \mathrm{~m}^{2}$ berbentuk trapesium dengan elevasi persegmen penampang melintang sebesar $0.1 \mathrm{~m}$ titik tinjau penampang sebelah kiri pada stasiun 18.18 , sementara titik tinjau penampang bagian kanan pada stasiun 80.49, lebar dasar saluran $9.1 \mathrm{~m}$, lebar muka saluran $6.23 \mathrm{~m}$, tinggi saluran $5 \mathrm{~m}$, dan tinggi banjir yang terjadi pada saluran hulu saat debit maksimum sebesar $2.17 \mathrm{~m}$ dari bawah permukaan tanah.

Berdasarkan Gambar 8, bentuk penampang melintang sungai pada bagian hilir tersebut memiliki luas $178.52 \mathrm{~m}^{2}$ dengan elevasi persegmen penampang melintang sebesar $0.1 \mathrm{~m}$ titik tinjau penampang sebelah kiri pada stasiun 18.18, sementara titik tinjau penampang bagian kanan pada stasiun 80.49 , lebar dasar saluran $9.1 \mathrm{~m}$, lebar muka saluran $6.23 \mathrm{~m}$, tinggi saluran $5 \mathrm{~m}$, dan tidak terjadi banjir pada saluran tersebut.

Tabel 1 menunjukkan nilai koefisien kekasran saluran (n) untuk berbagai jenis permukaan, telah dilakukan observasi lapang DAS Way Sekampung jenis permukaan saluran adalah tanah yang berkelok, maka nilai koefisien kekasaran manning ditetapkan sebesar 0.025 . Nilai tersebut seragam dari hulu hingga hilir saluran, dan digunakan untuk perhitungan geometri data di HECRAS. Peta banjir pada saat kondisi debit maksimum tersaji pada Gambar 9.
Tabel 1 Koefisien kekasaran saluran (n) untuk berbagai jenis permukaan

\begin{tabular}{lc}
\hline Jenis permukaan saluran & $\begin{array}{c}\text { Koefisien } \\
\text { kekasaran }(\mathrm{n})\end{array}$ \\
\hline Tanah (lurus dan seragam) & $0.017-0.025$ \\
$\begin{array}{l}\text { Tanah (berkelok, landai, } \\
\text { dan berumput) }\end{array}$ & $0.022-0.030$ \\
$\begin{array}{l}\text { Dasar berbatu dengan } \\
\text { lereng }\end{array}$ & - \\
Bersemak - semak & $0.025-0.040$ \\
Batu bata disemen & $0.012-0.017$ \\
Beton & $0.012-0.018$ \\
Lereng dengan & $0.025-0.033$ \\
trucuk/riprap & \\
\hline
\end{tabular}

Peta banjir pada Gambar 9 merupakan luas sebaran banjir serta luas wilayah banjir saat debit maksimum. Luas wilayah banjir maksimum sebesar 32.48 $\mathrm{m}^{2}$ pada bagian hulu sungai, hal tersebut dapat terjadi ketika debit maksimum, luas sebaran banjir minimum sebesar $0.001 \mathrm{~m}^{2}$ pada bagian hilir. Hasil perhitungan ini tergantung pada luas penampang saluran, kontur, dan debit. Upaya yang dapat dilakukan mengenai bahaya banjir adalah perbaikan saluran dan perlindungan dari vegetasi, partisipasi aktif dari masyarakat untuk menjaga agar saluran tetap terjaga dan memberikan informasi wilayah banjir.

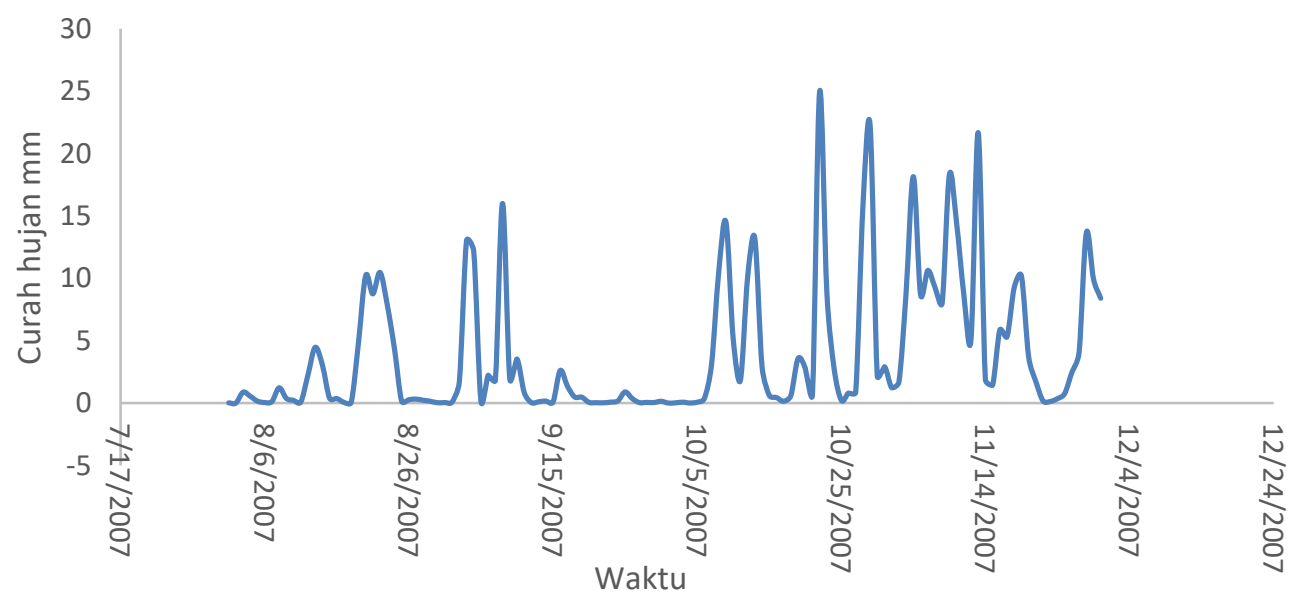

Gambar 5 Curah hujan rata-rata 


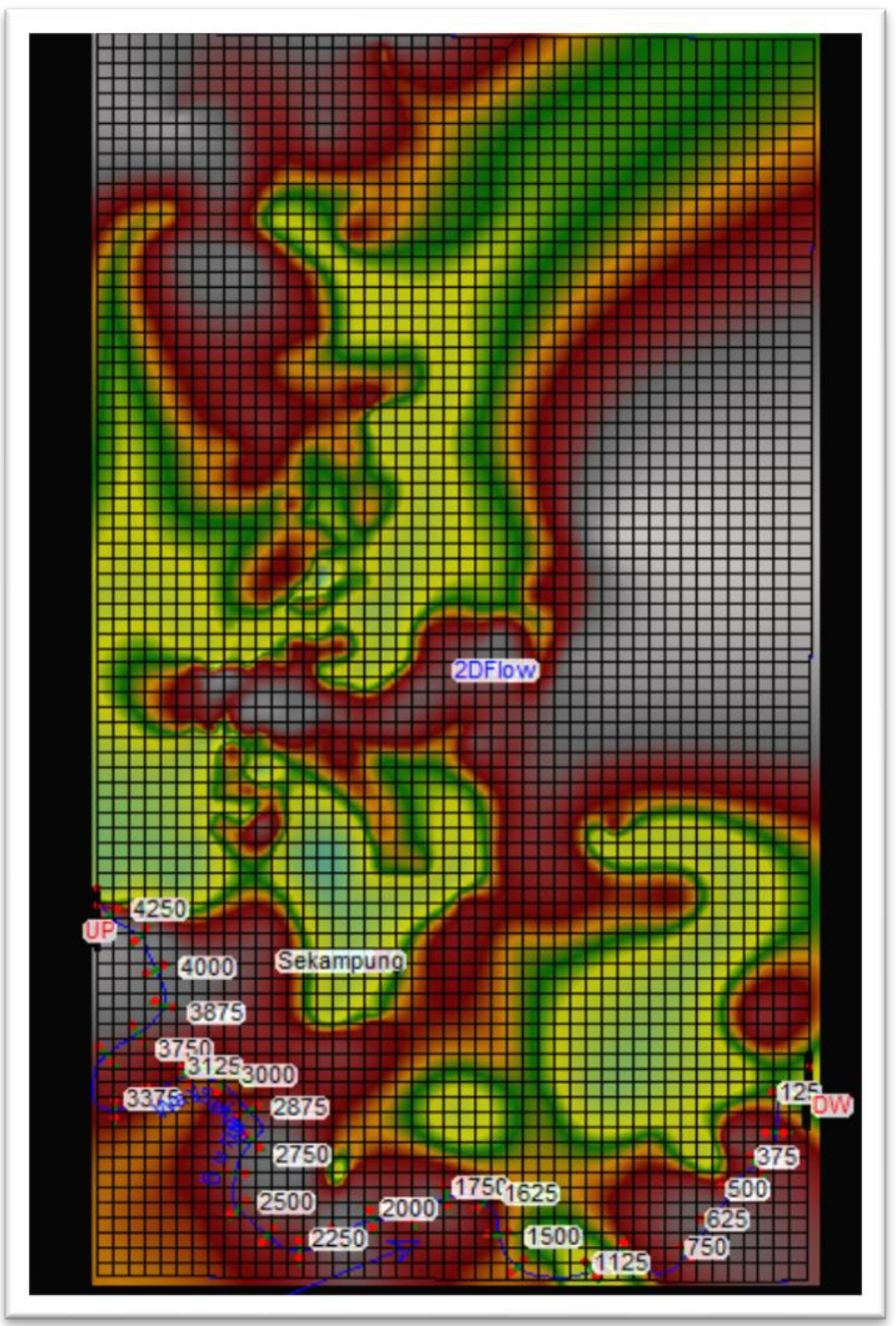

Gambar 6 Geometri data HEC - RAS

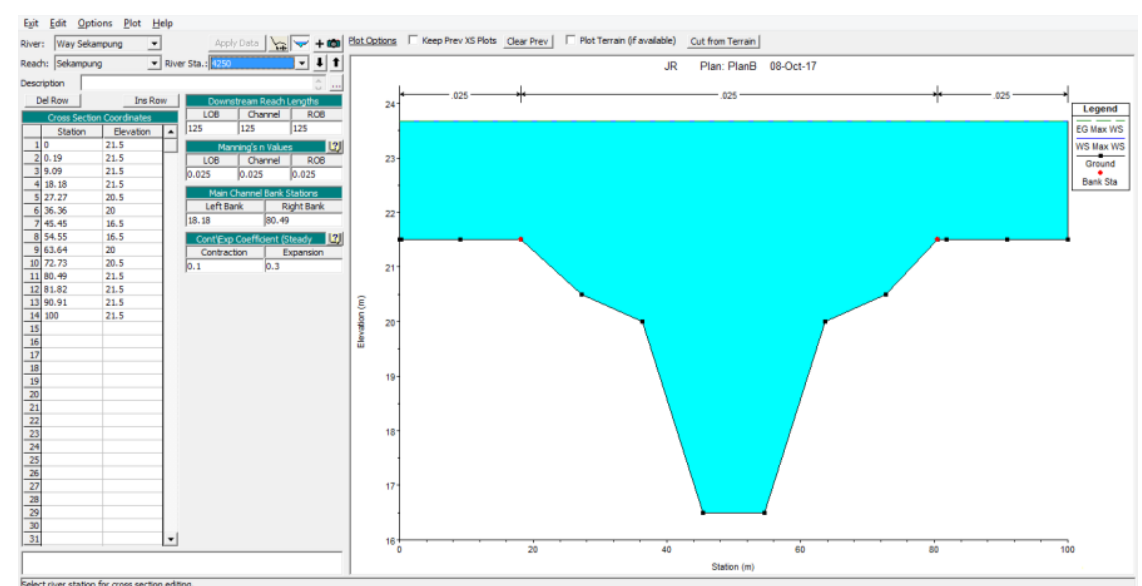

Gambar 7 Bentuk penampang melintang pada bagian hulu cross section 4250 


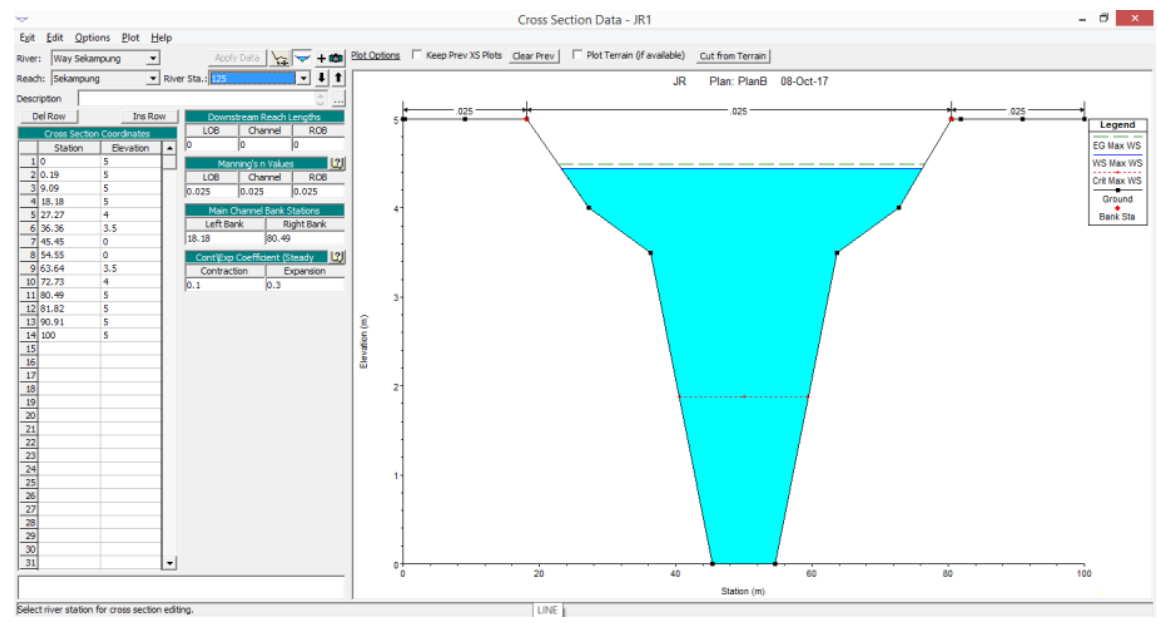

Gambar 8 Bentuk penampang melintang pada bagian hilir cross section 125

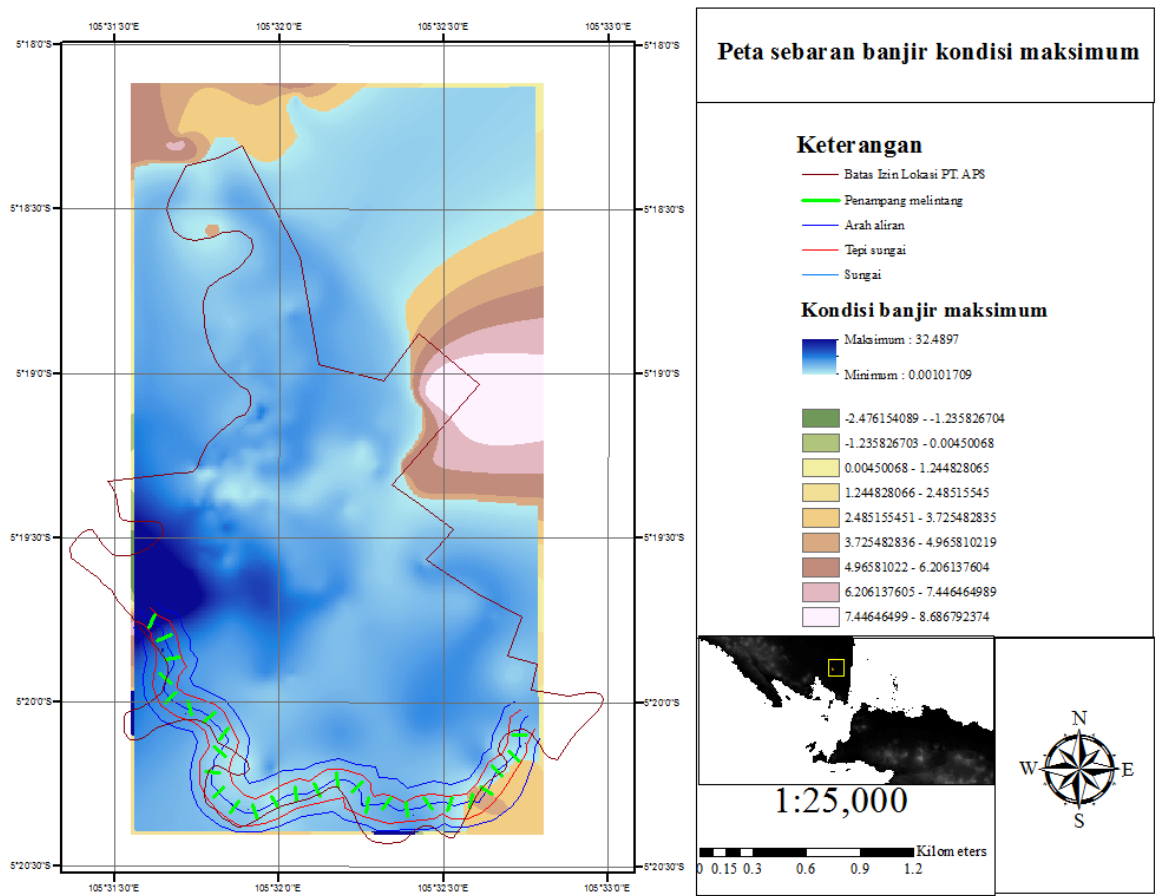

Gambar 9 Peta banjir saat kondisi debit maksimum

\section{KESIMPULAN}

Titik kontur pada pemetaan dibuat dengan mendapatkan nilai koordinat lapang dengan menggunakan RTK (Real time kinematic), yang dapat menentukan nilai koordinat $\mathrm{x}, \mathrm{y}$, dan nilai elevasi $\mathrm{z}$. Terdapat 294 data lapang yang selanjutnya diolah dengan ArcGIS membentuk kontur. Pemetaan dilakukan dengan aplikasi ArcGIS untuk mendapat model sungai, bantaran, arah aliran, dan penampang melintang. Debit hidrograf didapat dari hasil simulasi pada aplikasi SWAT. Debit puncak sebesar 97.90 $\mathrm{m}^{3} /$ detik terjadi pada 6 Oktober 2007 , debit minimum sebesar $19.25 \mathrm{~m}^{3} /$ detik terjadi pada 14 November 2007, dan rata - 
rata debit sebesar $41.14 \mathrm{~m}^{3} /$ detik. Penampang saluran berbentuk trapesium dengan luas $178.52 \mathrm{~m}^{2}$, elevasi per segmen $0.1 \mathrm{~m}$, lebar dasar saluran $9.1 \mathrm{~m}$, tinggi muka air di saluran $6.23 \mathrm{~m}$, tinggi saluran $5 \mathrm{~m}$, dan tinggi banjir yang terjadi pada saluran saat kondisi maksimum adalah $2.17 \mathrm{~m}$. Nilai koefisien manning yang digunakan sebesar 0.025 dengan tipe saluran tanah berkelok, landai, dan berumput. Sedangkan curah hujan maksimum pada pemetaan presipitasi sebesar $24.96 \mathrm{~mm}$, curah hujan minimum sebesar $0.0001 \mathrm{~mm}$, dan rata rata curah hujan sebesar $4.008 \mathrm{~mm}$. Luas sebaran wilayah banjir saat debit maksimum 32.48 $\mathrm{m}^{2}$ dan ketika kondisi minimum sebesar $0.001 \mathrm{~m}^{2}$ yang terjadi pada hulu sungai.

\section{DAFTAR PUSTAKA}

Kastamto. 2012. Prediksi morfologi dasar sungai akibat variasi tutupan vegetasi tebing Sungai Way Sekampung. Jurnal Teknik Sipil UBL. 3(2): 306 - 330.

Mustofa M J, Kusumastuti I D, Romdania Y. 2015. Analisis hidrologi dan hidrolika Pada Saluran Drainase Ramanuju hilir Kotabumi (menggunakan program HECRAS). Jurnal Rekayasa Sipil dan Desain. 3(2): 303 - 312.

Putrinda AC. 2012. Koefisien aliran permukaan di DAS Sekampung Provinsi Lampung tahun 1995 2010 [skripsi]. Jakarta (ID): Universitas Indonesia.

Purwono N. 2013. Pemodelan spasial untuk identifikasi banjir genangan di wilayah Kota Surakarta dengan pendekatan metode rasional (rational runoff method) [skripsi]. Surakarta (ID): Universitas Muhammadiyah Surakarta.

Rifai A. 2017. Analisis debit banjir di DAS Way Sekampung, Provinsi
Lampung dengan Pemodelan SWAT [skripsi]. Bogor (ID): Institut Pertanian Bogor.

Rosyidie A. 2013. Banjir: fakta dan dampaknya, serta pengaruh dari perubahan guna lahan. Jurnal Perencanaan Wilayah dan Kota. 24(3): $241-249$.

Santoso E B. 2013. Manajemen risiko bencana banjir Kali Lamong pada Kawasan Peri-Urban SurabayaGresik melalui pendekatan kelembagaan. Jurnal Penataan Ruang. 8(2) 48 - 59.

Sebastian L. 2008. Pendekatan pencegahan dan penanggulangan banjir. Jurnal Dinamika Teknik Sipil. 2(8): 162-169.

Sudaryono. 2002. Pengelolaan Daerah Aliran Sungai (DAS) terpadu, konsep pembangunan berkelanjutan. Jurnal Teknologi Lingkungan. 3(2): 153-158. 
